\title{
Editorial
}

\section{Teaching sexuality in Brazilian medical schools}

\section{Ensino da sexualidade na formação médica no Brasil}

\author{
Andrea Cronemberger Rufino ${ }^{1}$, Alberto Pereira Madeiro ${ }^{1}$
}

To include training in sexual medicine into the curricula of medical schools is justified because of the association between sexuality and health, which is commonly part of the discussion of practice of the medicine. This association is observed by the importance given to sexuality in interpersonal relationships and quality of life, and, also by the prevalence of sexual dysfunctions in the population. In addition, high expectations exist regarding training in sexual health for physicians, including the assistance for vulnerable groups such as lesbian, gays, bisexuals, and transgender individuals. ${ }^{(1,2)}$

Despite this current scenario of demands and expectations, several barriers are pointed out for adequate assistance in sexual health. Such barriers have been discussed for long-time and they are related with discomfort of professionals because of patients' sexual complaints along with beliefs about normative heterosexuality that reinforces vulnerabilities. The lack of communication ability to collect sexual anamnesis and the unknown intersection between sexuality and health are also highlighted factors. In this context recommendations are reinforced concerning improvements needed for teaching sexuality in medical schools. ${ }^{(3)}$
The offering of sexual-related topics in the curricula of medical school remains a discussion worldwide in studies related with sexuality in the last 65 years. The positive impact of sexual subjects inclusion in the curriculum of medical education was showed by students who pointed out sexual education as a tool able to help them to better deal with their own sexuality, recognize sexual diversity of individuals and give more consideration to patients' sexual complaints. ${ }^{(4)} \mathrm{A}$ consensus exist that sexuality must be offered in curricular model centered in the student and supported on the knowledge, attitudes and skills. ${ }^{(5)}$

Knowledge acquisition must cover biological, psychological and sociocultural aspects of sexuality. The topic "attitudes" is considered the most valuable one for the observation that students were unable to learn when facing discomfort situations. For this reason, to promote changes of attitude in situations that involve sexuality stimulate behavioral changes, improve the comfort of students with the subject their communication skills and, in addition, favor the absorption of knowledge. ${ }^{(6)}$

Skills acquisition prepares for assistance in sexual health. For this reason, communication skills that must be emphasized include

'Universidade Estadual do Piauí, Teresina, PI, Brazil.

Corresponding author: Andrea Cronemberger Rufino - Health Science Center of the Universidade Estadual do Piauí, Rua Olavo Bilac, 2.335 - Centro Sul Zip Code: 64001-120 - Teresina, Pl, Brazil - Phone: (86) 3224-4749 - E-mail: andreacrufino@gmail.com

DOI: 10.1590/S1679-45082015ED3306 
speak comfortably about sex, use of non-discriminatory language and appropriated for the gender. In addition, training is need to teach students collect sexual history, make physical-pelvic examination in patients and diagnose sexual dysfunctions in its organic, psychological and social aspects. ${ }^{(6)}$ Sexuality teaching must be provided in an interdisciplinary approach in order to reach all extension of medical schools' curricula, assuring the integrality of sexual health in medical education ${ }^{(5,6)}$

Several inquiries around the world were done with the aim to get to known the number of medical schools that offer training in sexuality during undergraduate studies, subjects given and time devoted for this purpose. $^{(3,7)}$ A recent national survey showed that 96.3\% of professors from 110 Brazilian medical schools offered sexuality-related topics with mean of 6 hours devoted to the discipline. However, this approach occurred by organic, pathologic and heteronormative bias in fragmented format in disciplines that do not communication among themselves. Psychological and social aspects of sexuality that influence sexual behavior were little addressed by professors. These data highlight the need of improvements in offering sexual education in Brazilian medical schools in order to guarantee integral care to sexual health of the population. ${ }^{(7)}$

\section{REFERENCES}

1. Leiblum SR. An established medical school human sexuality curriculum: description and evaluation. Sex Relation Ther. 2001;16(1):59-70.

2. National Center for Health Statistics. Healthy People 2010 final review [internet]. Hyattsville, MD; 2012 [Acesso em 29 ago. 2014]. Disponível em: http://www.cdc.gov/nchs/data/hpdata2010/hp2010_final_review.pdf

3. Coleman E, Elders J, Satcher D, Shindel A, Parish S, Kenagy G, et al. Medica school education in sexual health: Report of an expert consultation. J Sex Med. 2013;10(4):924-38.

4. Rufino AC, Madeiro AP, Girão MJ. 0 ensino da sexualidade nos cursos médicos: a percepção de estudantes do Piauí. Rev Bras Educ Med. 2013;37(2):178-85.

5. Eardley I. A curriculum for sexual medicine? J Sex Med. 2009;6(5):1195-8.

6. Kingsberg SA, Malemud CJ, Novak T, Cole-Kelly K, Wile MZ, Spanos P, et al. A comprehensive approach to enhancing sexual health education in Case Western Reserve University School of Medicine. Int J Impot Res. 2003;15(Suppl 5):S51-7.

7. Rufino AC, Madeiro AP, Girão MJ. Sexuality education in Brazilian medical schools. J Sex Med. 2014;11(5):110-7. 